\title{
DYNAMICS OF PATHOMORPHOLOGICAL CHANGES IN RAT ISCHEMIC SPINAL CORD AFTER TREATMENT WITH RECOMBINANT ERYTHROPOIETIN: EXPERIMENTAL STUDY
}

\author{
Alexey Volodchenko', Ravil Giniatullin², Arnold Kosel², Lyudmila Astakhova² \\ ${ }^{1}$ Department of Neurosurgery, Chelyabinsk Regional Clinical Hospital 3 \\ ${ }^{2}$ Chelyabinsk State Institute of Laser Surgery
}

\begin{abstract}
INTRODUCTION: There is ample current research on new methods of treatment for spinal cord infarction. In this respect, in recent years, recombinant erythropoietin (REP) has been gaining increasing interest among medical professionals; REP is a drug with proven protective activity in response to ischemia of different organs and tissues including the brain and the spinal cord.

We aim to study the dynamics of morphological changes in spinal cord ischemic lesions in rats influenced by REP.

MATERIALS AND METHODS: The study was conducted on $\mathbf{4 0}$ mature rats. The animals were divided into two series of experiments, 20 animals each. The first series of animals was the group compared to the spinal cord ischemia model. In the second series 1000 international units $(0.0084 \mathrm{mg})$ of REP in 3,24 , and 48 hours were administered intraperitoneally to the animals. After the animals had been sacrificed, the spinal cord was removed for further histologic and morphometric study. The obtained results were processed using analysis of variance. The statistical significance of differences between the compared parameters of the groups was assessed with the Mann-Whitney $U$ test.

RESULTS: The study of the spinal cord specimen showed that REP administration results in significantly higher levels of normal neurons and blood vessels, and in significantly lower count of chromatolytic neurons and ghost cells at all stages of the experiment.

CONCLUSION: At the early stages of the experiment, the REP effect increases the ischemic tolerance of neurons and enhances the proliferation rate of gliocytes and endotheliocytes with the development of a new blood stream.
\end{abstract}

Keywords: spinal cord, experimental ischemia, pathomorphological and functional disorders, recombinant erythropoietin

Address for correspondence:

Alexey Volodchenko

Chelyabinsk Regional Clinical Hospital 3

pr. Pobedy 287

454021, Chelyabinsk

Russian Federation

e-mail:volodchenko174@yandex.ru

Received: February 26, 2016

Accepted: April 18, 2016 


\section{INTRODUCTION}

The incidence of spinal cord vascular diseases is much higher than it was believed. According to recent statistics, the ratio of cerebrovascular diseases to spinal cord vascular diseases is $4: 1$.

Spinal cord infarction is a circulatory disturbance of the spinal cord that causes a spinal cord injury and dysfunction due to insufficient or blocked blood supply.

The damaging effect of ischemia results in irreversible neuronal changes - the formation of focal necrosis and infarct core (1). For several hours the area of the central "punctate" infarction is surrounded by ischemic, but viable tissue - the so-called ischemic penumbra (2). In the area of the penumbra, the energy metabolism is mostly preserved, and the changes are functional, not structural (3). It is the region of "critical" or "misery" perfusion where the neuronal function is reduced because the tissue metabolic demands are not met, but the cells are viable, and their ionic homeostasis is preserved. Early and appropriate drug delivery to the area of penumbra prevents neuronal cytolysis.

For this reason, there is ample current research on new methods of treatment for spinal cord infarction. In this respect, in recent years recombinant erythropoietin (REP) has been gaining increasing interest among medical professionals; REP is a drug with proven protective activity in response to ischemia of different organs and tissues including the brain (4) and the spinal cord (5). It has been established that REP has anti-apoptotic and anti-hypoxic effect, stimulates angiogenesis and neurogenesis (4, 6-8), and the pleiotropic action of REP is associated with specific receptors at the surface of different cells including neurons (9).

\section{MATERIALS AND METHODS}

We conducted our study on 40 mature outbred rats of both sexes, 200-250 g of weight. All animals were divided into 2 series of experiments.

\section{$1^{\text {st }}$ Series of Experiments}

Using the technique suggested by Sufianova et al. (10) we modeled spinal cord ischemia in 20 animals (control group). Transient ischemia of the lumbar spinal cord was induced with total intravascular occlusion of the abdominal aorta and its branch- es. For this purpose, occluders (sterilized 3-0 chromic catgut) were inserted into both femoral arteries towards the heart; insertion depth was determined based on the distance between the xiphoid process and the tail set. After that, $0.3 \mathrm{ml}$ of $3 \%$ feracrylum solution was introduced into left common carotid artery, below the site of ligation, towards the occluders. 45 minutes later the occluders were removed, and the femoral arteries were clipped. The animals were sacrificed on days $3,7,14$, and 30 after the ischemia modeling. We have examined 5 rats at each stage of observation.

\section{$2^{\text {nd }}$ Series of Experiments}

In 20 animals we modeled spinal cord ischemia using the technique described above $\left(2^{\text {nd }}\right.$ series of experiments). Three hours after the operation, 1000 international units (IU) $(0.0084 \mathrm{mg})$ of recombinant erythropoietin («EPOKRIN $2000 \mathrm{ME})$ ) at the rate of $5000 \mathrm{IU}(0.0420 \mathrm{mg})$ per kg of bodyweight was administered intraperitoneally to each animal. 24 and 48 hours after creation of ischemia the drug administration was repeated in a dose of 1000 IU (0.0084 $\mathrm{mg})$. The animals were sacrificed on days $3,7,14$, and 30 after the ischemia modeling. We have examined 5 rats at each stage of observation.

After the animals were sacrificed, we prepared histological sections of the spinal cord and stained them with hematoxylin and eosin for microscopic investigation; the Bielschowsky technique was used for visualization of the myelinated fibers, and the Nissl staining was used for analysis of the Nissl substance. Microsections were investigated with a Leica DMRXA microscope (Germany).

For the objective assessment of the parameters of morphological changes we considered the following values: 1) count of intact (normal) neurons per unit area; 2) count of chromatolytic neurons per unit area; 3) count of ghost cells per unit area; 4) number of small blood vessels (capillaries and arterioles) per unit area.

Morphometric studies were conducted using DiaMorf Cito-W color image analysis software (Russia) at microscope magnification $\mathrm{x} 400$, in 10 random fields of view.

The obtained results were processed by IBM PC using Statistica 6.0 software suite (StatSoftIns, USA). Methods from variation statistics were used. The sta- 
Alexey Volodchenko, Ravil Giniatullin, Arnold Kosel et al.

tistical significance of the differences in the compared parameters in the groups was evaluated with the Mann-Whitney $U$ test. The differences were considered significant at $\mathrm{P}<0.05$ which corresponds to $95 \%$ confidence interval.

\section{RESULTS AND DISCUSSION}

Histologic study of lumbar enlargement specimens from the first series of experiments revealed the most prominent changes in the ventral horns chromatolysis of cytoplasm, nuclear pyknosis, and dissolution of the basophilic substance in neurons so that they turned into ghost cells. Intact and hyperchromic neurons were also seen. Neuronophagia was revealed, as well as pericellular and perivascular edema in the white matter. On day 7, in the central area of ischemic focus, destructive changes in the neurons were observed, and intact neurons were also seen in the perifocal area. The number of hypertrophic astrocytes was increased, activation of microglia was observed, and macrophages were seen. By days 14 and 30, the morphological changes in the spinal cord tissues were similar to those on day 7. At the same time, in the ischemic area a glial-connective tissue cicatrix was formed.

According to the results of the quantitative study of spinal cord specimens of the first series of experiments, the count of normal neurons $(24.3 \pm 1.1)$ was significantly lower only on day 7 , and the count of chromatolytic neurons was notably growing from day 7 (36.4 \pm 0.9$)$ till the end of experiment. In turn, the count of ghost cells was also growing, but the significant increase was only on day $7(58.1 \pm 2.5)$, and the number of blood vessels significantly increased on day $30(10.2 \pm 0.6)$ of observation (Table 1$)$.

The study of spinal cord specimens of the second series of experiments on days 3 and 7, and at further stages of observation (days 14 and 30) revealed that neurons were mostly preserved, though there were occasional hyperchromic cells, but only a few cells had signs of swelling or shrinkage. Capillaries and arterioles were hyperemic, and their endothelial cells had a high proliferation rate. At all stages of the experiment there were no glial-connective tissue cicatrices which indicated the low expression of ischemic injury, without formed necrotic zone in the spinal cord tissues.

The morphometric analysis of spinal cord specimens from the second series of experiments showed that the count of normal neurons in comparison with the pervious stage of experiment increased insignificantly, except on day $7(81.8 \pm 2.8)$, and the count of chromatolytic neurons significantly decreased on day $7(20.1 \pm 0.8)$, day $14(17.1 \pm 0.5)$ and day $30(12.2 \pm 0.3)$. At the same time, the count of ghost cells was significantly decreasing: $10.1 \pm 0.2$ (day 7); $8.3 \pm 0.4$ (day 14); $3.8 \pm 0.5$ (day 30). The number of small blood vessels was significantly higher on day $7(11.9 \pm 0.2)$ and day $30(17.3 \pm 0.3)$. Besides, the count of normal neurons and the number of small

Table 1. Dynamics of quantitative changes in the examined parameters of ischemic spinal cord tissues in rats from the different series of experiments $(M \pm m)$

\begin{tabular}{|c|c|c|c|c|c|}
\hline \multirow{2}{*}{$\begin{array}{l}\text { Examined param- } \\
\text { eter (per unit area) }\end{array}$} & \multirow{2}{*}{$\begin{array}{c}\text { Series of } \\
\text { experiment }\end{array}$} & \multicolumn{4}{|c|}{ Stage of observation (days) } \\
\hline & & 3 & 7 & 14 & 30 \\
\hline $\begin{array}{l}\text { Count of normal } \\
\text { neurons }\end{array}$ & $\begin{array}{l}1^{\text {st }} \\
2^{\text {nd }}\end{array}$ & $\begin{array}{l}30.2 \pm 2.1 \\
69.3 \pm 3.1^{* *}\end{array}$ & $\begin{array}{c}24.3 \pm 1.1^{*} \\
81.1 \pm 2.8^{* * *}\end{array}$ & $\begin{array}{l}27.8 \pm 1.3^{*} \\
87.7 \pm 2.5^{* *}\end{array}$ & $\begin{array}{c}29.9 \pm 2.5 \\
90.8 \pm 3.5^{* *}\end{array}$ \\
\hline $\begin{array}{l}\text { Count of chromato- } \\
\text { lytic neurons }\end{array}$ & $\begin{array}{l}1^{\text {st }} \\
2^{\text {nd }}\end{array}$ & $\begin{array}{c}29.3 \pm 0.6 \\
25.2 \pm 0.4^{* *}\end{array}$ & $\begin{array}{c}36.4 \pm 0.9^{*} \\
20.1 \pm 0.8^{* . * *}\end{array}$ & $\begin{array}{c}43.6 \pm 2.1^{*} \\
17.1 \pm 0.5^{* * *}\end{array}$ & $\begin{array}{c}53.8 \pm 1.2^{*} \\
12.2 \pm 0.3^{* * *}\end{array}$ \\
\hline Count of ghost cells & $\begin{array}{l}1^{\text {st }} \\
2^{\text {nd }}\end{array}$ & $\begin{array}{c}36.2 \pm 2.3 \\
15.2 \pm 0.3^{* *}\end{array}$ & $\begin{array}{c}58.1 \pm 2.5^{*} \\
10.1 \pm 0.2^{* * * *}\end{array}$ & $\begin{array}{l}63.8 \pm 2.8 \\
8.3 \pm 0.4^{* . * *}\end{array}$ & $\begin{array}{l}67.9 \pm 2.2 \\
3.8 \pm 0.5^{* * *}\end{array}$ \\
\hline $\begin{array}{l}\text { Number of small } \\
\text { blood vessels }\end{array}$ & $\begin{array}{l}1^{\text {st }} \\
2^{\text {nd }}\end{array}$ & $\begin{array}{l}4.3 \pm 0.2 \\
7.9 \pm 0.1^{* *}\end{array}$ & $\begin{array}{c}6.2 \pm 0.4 \\
11.9 \pm 0.2^{* * * *}\end{array}$ & $\begin{array}{c}8.1 \pm 0.7 \\
16.8 \pm 0.5^{* . * *}\end{array}$ & $\begin{array}{l}10.2 \pm 0.6^{*} \\
17.3 \pm 0.3^{* *}\end{array}$ \\
\hline
\end{tabular}

Note: the $1^{\text {st }}$ series of experiments - spinal cord ischemia model (control group); $2^{\text {nd }}$ series of experiments - spinal cord ischemia model treated with REP; ${ }^{*}-p<0.05$ in comparison with the previous stage of observation for each series of experiments; ${ }^{*}-p<0.05$ in comparison with the $1^{\text {st }}$ series of experiments. 
blood vessels was significantly higher, and the count of chromatolytic neurons and ghost cells was significantly lower at all stages of observation in comparison with the $1^{\text {st }}$ series of experiments (Table 1).

\section{CONCLUSION}

Thus, in all animals with spinal cord ischemia treated with recombinant erythropoietin the histologic study of spinal cord specimens on days 3 and 7 of experiment, as well as at further stages of observation (days 14 and 30), revealed that neurons were mostly preserved, though there were occasional hyperchromic cells, but only few cells had signs of swelling or shrinkage. At the same time, the count of ghost cells was decreasing - and significantly on day 7 - in comparison with day 3 . The number of blood vessels significantly increased on days 7 and 14 of the experiment. Besides, the count of chromatolytic neurons and ghost cells was lower at all stages of experiment in comparison with the animals from the control group.

The study of the model of rat lumbar spinal cord ischemia induced with total intravascular occlusion of the abdominal aorta and its branches revealed neuroprotective and angiogenic effect of recombinant erythropoietin expressed in the significant increase of neuronal resistance to injury and in the increased number of small blood vessels in the ischemic area.

\section{REFERENCES}

1. Fisher M, Takano K. Baillière's clinical neurology: Cerebrovascular disease. Hachinski V, editor. London: Baillière Tindall; 1995. p. 279-96.

2. Astrup J, Siesjo BK, Symon L. Thresholds in cerebral ischemia the ischemic penumbra. Stroke. 1981;12:723-5.

3. Symon L, Branston NM, Strong AJ. The concepts of thresholds of ischaemia in relation to brain structure and function. J Clin Pathol Suppl (R Coll Pathol). 1977;11:149-54.

4. Siren AL, Fratelli M, Brines M, Goemans C, Casagrande S, Lewczuk P, et al. Erythropoietin prevent neuronal apoptosis after cerebral ischemia and metabolic stress. Proc Natl Acad Sci USA. 2001;98;4044-49.

5. Inagaki S, Kitos S. Peptides in the peripheral nervous system. Progr Brain Res. 1986;66;269-316.
6. Celik M, Gökmen N, Erbayraktar S, Akhisaroglu $\mathrm{M}$, Konakc S, Ulukus C, et al. Erythropoietin prevents motor neuron apoptosis and neurologic disability in experimental spinal cord ischemic injury. Proc Natl Acad Sci USA. 2002;99;2258-63.

7. Santhanam AV, Katusic ZS. Erythropoietin and cerebral vascular protection: role of nitric oxide. Acta Pharmacol Sin. 2006;27;1389-94.

8. Wang L, Zhang Z, Wang Y, Zhang R, Chopp M. Treatment of stroke with erythropoietin enhances neurogenesis and angiogenesis and improves neurological function in rats. Stroke. 2004;35;1732-37.

9. Masuda S, Nagao M, Takahata K, Konishi Y, Gallyas F Jr, Tabira T, et al. Functional erythropoietin receptor of the cells with keural characteristics. Comparison with receptor properties of erythroid cells. J Biol Chem. 1993;268;11208-16.

10. Sufianova GZ, Usov LA, Sufianov AA, Shapkin AG, Raevskaya LY, Golubev SS. New minimal invasive model of rat spinal cord ischemia. Bull Exp Biol Med. 2002;133;1;116-20. 